\title{
THE INFLUENCE OF ENGLISH SONG TOWARD STUDENTS' VOCABULARY MASTERY AND STUDENTS' MOTIVATION
}

\author{
By \\ Eva Faliyanti \\ Muhammadiyah University of Metro \\ evafaliyanti1980@gmail.com
}

\begin{abstract}
Learning vocabulary is the important aspect for the students when they are studying English. The students need fresh method to make them enjoy in learning process. The teacher should be able to deliver the material well. Using media appropriately is also needed for teachers. The objectives of this research are to know whether English song can improve the students' vocabulary at the second semester of English education study program in University of Muhammadiyah Metro, to reveal whether English song English song influence the students' motivation at the second semester of English education study program in learning process, to portray how much English song influence the students' vocabulary mastery and students' motivation at the second semester of English education study program in academic year 2015/2016

The population in this research is 40 students. It is consist 2 classes and each class consists of 20 students..The result of the data analysis proved that the value of $t$-test $\left(\mathrm{t}_{\mathrm{obs}}\right.$ is 8,742 and $t_{\text {table }}$ is 2,021$)$. It means that $t_{\text {obs }}$ is higher than $t_{\text {table }}(8,742>2,021)$. Based on the criteria for testing hypothesis was if the value of $t$ obtained is higher than $t$ table at significant level 0,05 the null hypothesis (Ho) is rejected and hypothesis alternative (HI) is accepted. After viewing the result of One Sample t-test, the writer came to conclusion that "there was significant Influence of English Song Toward Students' Vocabulary Mastery and students' motivation at the second semester of English education Study Program in the Muhammadiyah University of Metro Academic Year 2015/2016".
\end{abstract}

Key words: English song, Students’ Motivation, Vocabulary Mastery.

\section{INTRODUCTION}

English is the foreign language in Indonesia not only in our country but also other country. It is very important because all of the countries use it to communicate each other. It proves that language is necessary for people to interact with other people. Language is not released from vocabulary. When the students try to speaking English in a good way they must master the vocabulary as much as they can. They have to memorize it and to memorize the vocabulary is not easy. The lecturer had to facilitate them to memorize the vocabulary. 
Some students feel afraid and lazy to learn English. It is because they feel that English is very difficult to learn. They have difficulty in their own language moreover for other language. They give up before fighting. They also seldom or never use English in their daily life

Technique is one way that used by the lecturer to improve the students' English ability, especially in vocabulary The teacher has responsibility to create and determine the way that can be used to improve the students' English. The goal of the result is base on how the lecturer teaches. How lecturer teach can determine the result in the learning process. There are many techniques that teachers give for the students, such as puzzle, words games, words selection, picture, and song. The lecturer should choose the appropriate technique to make the materials more enjoyable, challenging, and interesting.

The researcher asked to the students of English education study program in Muhammadiyah University of Metro, and they answered that they felt difficult to memorize the words. The effect was they cannot speak fluently. Most of them were interested to speak English, but their vocabulary was not too much. They realized that memorize the vocabulary was very important. Besides, their school did not have them memorize the words. They also said that they were lazy when they had to memorize the words by reading word by word. The researcher would like to do research by using song to make them easier in memorizing of words.

In this research, the researcher uses song as the alternative media because listening song can create an enjoyable in learning process. It also does not make them bored. When the students do not feel bored in learning process, it can make them easier to accept the material. Song is valuable aids in developing students listening skill. There are many advantages students get by using it. When the researcher offered it to them, they were very excited. Because of that, the researcher was so spirit to use for research. Based on the explanation above and the researcher has a motivation to do the research by finding out the influence of English Song toward Students Vocabulary Mastery and Students Motivation

\section{The Song}

Doren in Andianto (2010) states that song is a short musical work set to a poetic text, with equal importance given to the music and the words. It may be written for one or several voices and generally performed with instrumental accompaniment. Redlich in Andianto (2010) also adds that song is short composition usually for one voice based on lyric or poem. The lyric and the text are very various. They can be simple song or long song; can be in the form of sentences or just a word, even syllable and they usually combine with the music. 
While Griffe (1995) in Septiani (2010) say that the word song refers to pieces of the music that have words. Based on that explanation, it can be conclude that song is combining between words to other word to be short piece.

\section{Vocabulary Mastery}

Vocabulary is one of the language aspects which should be learnt. Learning vocabulary is important because it is able to speak, write, and listen. They have to know vocabulary first. According to Bailey (2001) a word when they can recognize its meaning when they see it It means that in learning vocabulary, they have to know the meaning of it and also understand and can use it in sentence context. According to Frank (2000) vocabulary is knowledge involves knowing the meanings of words and therefore the purpose of vocabulary test info find out whether the learners can match each word with a synonym, a dictionary, or an equivalent word with their own language. In learning, we have to know the meaning of words itself and can use it in sentence automatically.

Kriedler in Septiani (2010) states that in modern language, learning vocabulary is not long that consist of memorizing list of words in isolation, lasted, and words usually give a meaning full context and practice in appropriate patterns. Longman in Septiani (2010) explaine that vocabulary is list of words, usually in alphabet order and with explanation of their meaning, less complete than dictionary. It means that they should understand the meaning. Wilkins in Septiani (2010) say that without grammar could be conveyed, without vocabulary could not be conveyed. So, it can be conclude that someone cannot convey anything without vocabulary. Vocabulary is the vital aspect of the language Hornby, (1953) in Yuniarti (2011). It means that in order to able to communicate with one language, students have to process adequate its vocabulary. Based on the explanation above, it can confirm that vocabulary is a very important part in learning language. By knowing much vocabulary, students can understand what someone says or can communicate with other people

Without vocabulary, they cannot say anything because vocabulary is a basic to be able to speak. They measure the quality of the students from the quality and quantity of their vocabulary. The lecturer had to support them to memorize the words as much as they can. So, they can use it in daily life or in the entire situation. To support the learning process and to make it easier, the teacher should use simple vocabularies that can easily understood by the students. One of the most effective ways to teach English is through song. The students love to sing and play. The rhythm and repetition of songs may make it easier for very young children to remember the vocabulary. It is much easier to keep their attention on learning 
when they are singing or dancing. Song has an important thing like tone and lyric. Tone has lilting voice that make students brought in imagination. Kinds of song are very various like pop, rock, jazz, classic, reggae, traditional and modern. And every student has different style in their favorite song. The students can choose what their favorite song is. Song is also easy to find. Everyone can listen song every time and everywhere. Song does not make the students bored because it is more variety. When the students do not feel bored, they will be more motivated to study. The students also do not feel sleepy when they are in learning process. Memorizing the vocabulary is easier by listen a song than other way. Most of students like listening song. The students like listen their favorite song. They will remember it when they always hear a song. When they like with the song, they will memorize the lyric of the song.

\section{Motivation}

According to Schunk (20013) motivation is an energy change within the person characterized by affective arousal and anticipatory goal reactions. It means that someone will get a goal if they do activities. And their activities need strong motivation to reach it. Ferlazzo (1998) believes that the attitude of human is instructed and awakened by certain requirements, safety, love, respecting, knowing, understanding and others. The requirements can motivate someone behavior. Someone who wants to do activities in learning needs motivation inside. And someone who has not motivation inside, they need it outside.

The criteria of the motivation can be seen from intrinsic and extrinsic. The criteria from intrinsic are persistence in learning, though in face difficulties, and stand alone in learning. And the criteria from extrinsic are goal achievement and environment.

Upon all, this study tries to find out the influence of English song toward vocabulary mastery and thus the research question: Is there any influence and significant of using English song toward students' vocabulary mastery and students' motivation at the second semester Students of English education study program in Muhammadiyah University of Metro?

\section{METHOD}

In this research, the researcher uses experimental method. It is intended to find out the influence or the result of implementing the media. As experimental typically involves two groups, an experimental groups and a control group. One group is an experimental class and the other one is a control class. The subject of this research is the second semester of students Muhammadiyah University of Metro in academic year 2015/2016. The characteristic of this 
research is descriptive quantitative. The experimental group gave treatment using song by the researcher. The control group like usual. The lecture teach the students and the researcher does not investigate the control group.

\section{Pre-test and Post-test}

Pre-test means the first way to get information about the students' vocabulary mastery before the treatment is given. The researcher gives the test for the students to know about the students' ability before doing research. And the test is given for experimental class and control class. Post-test is to measure students' achievement in vocabulary mastery after the treatment is given. The researcher gives test to know whether the treatment is success or not.

\section{Questioner Sheet}

Questioner is a collecting data technique which done by giving a set of question or statement written for respondent to answer (Sugiyono, 2011). The questioner is given to know students' motivation before and after giving the treatment. Researcher gives the students some questions about their intention of motivation.

\section{Data Collecting Technique}

In this research, the researcher uses two tests. Pre test and Post Test and also Observation will do to know the students' atitute (qualitative data) during the research. The research data of this research as follow : the first, in this research the researcher uses written test to collect the data. The second is questionnaire. The researcher gives unquote before and after giving post-test. The unquote is used to know whether the motivation of the students is low or high.

\section{Data Analysis Technique}

In this research, the researcher validated this data by using writing test and observation. After getting data from test and observation, the researcher analyzed the data based on the limitation of the problems and objectives of the research.

\section{RESULT AND DISCUSSION}

\section{Result and Discussion}

Based on the research finding and the result of the calculation of students' vocabulary mastery and students' motivation taught using English song for experimental group and control group taught without song, The writer concluded that there are some important parts as follows: 
The condition of students' vocabulary mastery and students' motivation both of experimental group and control group in the beginning are relatively same. They are shown by the result of the pre tests of them. The mean scores of two groups are 54.23for experimental group and $\mathbf{5 2 . 6 9}$ for control group. It can be said that there is no significant different of students' vocabulary mastery and students' motivation both two groups.

Based on the result of the data on post-test, it is found that there is a significant different in vocabulary mastery between students taught listening using song and without song. The mean scores of pronunciation for experimental group taught using song higher than control group that taught without using song they are 65.81>57.37. It can be said that teaching vocabulary through listening English song more effective to improve students' vocabulary mastery than without song. On the other hand, teaching vocabulary through listening English song can increase students' vocabulary.

Furthermore, the result of data analyses proved that the value of t-test $\left(t_{o b t}\right)$ is 9.70 and $t_{\text {table }}$ is 2,06 . It means that the $t_{\text {obt }}$ higher than $t_{\text {table. }}$ Based on the criteria for testing hypotheses was if value $t_{o b t}$ is higher than $t_{\text {table }}$ at significant level of 0,05 , the null hypotheses $\left(\mathrm{H}_{\mathrm{O}}\right)$ is rejected and alternative hypotheses $\left(\mathrm{H}_{\mathrm{I}}\right)$ is accepted.

\section{CONCLUSION AND SUGGESTION}

\section{Conclusion}

Based on the result of the research, the data analysis and discussion, the conclusion can be drawn as follow: From the data, the researcher concluded that there was significant influence of English song toward students' vocabulary mastery at the second semester of English education study program in the Muhammadiyah University of Metro academic year $2015 / 2016$. It can be seen from the result of the hypothesis testing. It shows that $t$ obtained is 9.70 and $t$-table is 2,06 at the significant level 0,05 . It means that $t$ obtained is lower than $t-$ table. That is why, the null hypotheses $(\mathrm{Ho})$ is rejected and the alternative hypotheses $\left(\mathrm{H}_{\mathrm{I}}\right)$ is accepted at the significant level of 0,05 .

Using song in listening process had contribution and significant effect for the students and the teacher. the students enjoyed and they were fun in accepting information especially the new experience in learning of listening, while the teacher was easier in transferring material to the students how to speak English words correctly. Besides, the students 
understood better about vocabulary and how to write it. So, they could wrote better than before. Based on the result and discussion, the researcher concluded that song is effective in listening learning process for the students at the second semester of English education study program in the Muhammadiyah University of Metro.

\section{Suggestion}

After conducting the research, the researcher proposes some suggestion there are From the result of the research shows that in order to increase students' learning outcomes in vocabulary mastery, song is media that effective to use in the learning process. By using song, the students get good progress in vocabulary mastery.

To make students' vocabulary improved, can use media which make students more interested to study. Besides, to increase the students' motivation, song is one of media that can be used in the class.

\section{BIOPROFILE}

Eva Faliyanti is an active lecturer in English Education Study Program Of Muhammadiyah University of Metro since 2008. She graduated from Ahmad Dahlan University of Yogyakarta 2004. She continued the Magister of English Education in Ahmad Dahlan University of Yogyakarta. Her interest is in vocabulary. Corresponding email:

\section{evafaliyanti1980@gmail.com}




\section{REFERENCES}

Andianto.(2010). The Influence of Teaching Listening Through Song Toward Students' Pronunciation Ability at The Second Year of SMA Muhammadiyah 2 Metro Academic Year 2009/2010. Unpublished Thesis.

Bailey, K. D. (2001). Methods of Social Research: Fourth Edfition. New York: The Free Press

Ferlazzo, L. (1998). Self Motivated Learners. Eye on Education book

Frank, M. (2000). Modern English. A practical Refence Guide. New Jersey: Prentice-Hall, Inc

Schunk, D.H. (2013). Motivation in Education. Pearson

Septiani, R. (2010). Increasing the Students' Vocabulary Mastery through English Song at the Second Graders of SMP 1 Purbolinggo. Unpublished Thesis

Sugiyono. (2011). Metode Penelitian Pendekatan Kuantitatif, Kualitatif, dan R\&D. Bandung: C.V Alfabeta

Yuniarti. (2011).The Influence of using song as the instructional media toward the students' vocabulary mastery of fifth graders at SDN 01 Taman Cari Academic Year 2010/2011. Unpublished Thesis 